\title{
AC loss of HTS magnet for AMR refrigerator using magnetic field formulation and edge element in cylindrical coordinates
}

\author{
Seokho Kim ${ }^{*}$, , Minwon Park ${ }^{\mathrm{a}}$, and Sangkwon Jeong ${ }^{\mathrm{b}}$ \\ ${ }^{a}$ Changwon National University, Changwon, Korea \\ ${ }^{\mathrm{b}}$ KAIST, Daejeon, Korea
}

(Received 18 February 2013; revised 15 March 2013; accepted 16 March 2013)

\begin{abstract}
AMR (Active Magnetic Regenerative) refrigerators require the large variation of the magnetic field and a HTS magnet can be used. The amount of AC loss is very important considering the overall efficiency of the AMR refrigerator. However, it is very hard to estimate the precise loss of the HTS magnet because the magnetic field distribution around the conductor itself depends on the coil configuration and the neighboring HTS wires interact each other through the distorted magnetic field by the screening current Therefore, the AC loss of HTS magnet should be calculated using the whole configuration of the HTS magnet with superconducting characteristic. This paper describes the AC loss of the HTS magnet by an appropriate FEM approach, which uses the non-linear characteristic of HTS conductor. The analysis model is based on the 2-D FEM model, called as 'magnetic field formulation and edge-element model', for whole coil configuration in cylindrical coordinates. The effects of transport current and stacked conductors on the AC loss are investigated considering the field-dependent critical current. The PDE model of 'Comsol multiphysics' is used for the FEM analysis with properly implemented equations for axisymmetric model.
\end{abstract}

Keywords : AMR refrigerator, AC loss, HTS magnet

\section{1. 서 론}

자기냉동기(magnetic refrigerator)는 이론적으로 카르노 냉동기의 효율을 구현할 수 있으며, 프레온과 같은 지구 온난화 물질을 사용하기 않기 때문에 최근 상온 냉동 사이클뿐만 아니라, 수소의 액화 및 재액화를 포함한 극저온 냉동 사이클에 적용하기 위한 연구가 진행되고 있다 [1]-[4].

자기냉동기는 기체 냉매가 압축기에 의해서 온도가 상승하고 팽창에 의해 온도가 내려가는 것과 마찬가지로 외부 자기장에 의해 자기냉매(magnetic refrigerant)가 자화되면 온도가 상승하고 탈자될 때 온도가 내려가는 자기 열량 효과(MagnetoCaloric Effect; MCE)를 이용한다. 따라서, 고효율 자기냉각 시스템을 구현하기 위해서는 압축기를 대신할 고자장 자석을 필요로 한다.

특히, 영구자석 혹은 상전도 자석으로 발생시킬 수 있는 자기장보다 더 큰 자기장을 발생시키기 위해서는 초전도 자석을 고려할 수 있다.

자기냉동기를 구현하기 위해서는 자기냉매에 작용하는 자기장의 변화를 크게 해야 하며, 이를 위해서는 자석과 자기냉매의 상대 위치를 연속적으로 변경시키는 방법과 자기장의 세기 자체를 변화시키는 방법이 있다. 상대 위치를 변화시키기 위해서는 자석 혹은 자기냉매를 움직여야 한다는 단점이 있으며, 자기장의 세기를 변화시키기 위해서는 고온 초전도 자석에 교류 전류를 통전시킴으로써 해결이 가능하다. 그러나, 고온 초전도 자석의 경우 일반적으로 많이 알려진 바와 같이 외부의 자기장 변화 및 자체 통전 전류의 변화에 의해 통전손실이 발생하는 것으로 알려져 있다.

\footnotetext{
* Corresponding aurhor: seokho@changwon.ac.kr
}

자기냉동기의 경우 상용 주파수인 $60 \mathrm{~Hz}$ 보다 매우 낮은 주파수로 운전이 되지만, 극저온 자기냉동기의 작동 온도 및 효율을 고려하였을 때, 초전도 자석의 통전손실에 대한 정 밀한 예측은 필수적이다.

초전도체의 자화손실은 변화하는 외부자장 내에서 초전 도 선재 시편의 자화량을 측정하는 연구가 많이 이루어졌으 며 [5] - [6], 유한 요소법을 이용하여 초전도체 내부에 발생 하는 차폐전류(screening current)를 해석함으로써 자화 손실(magnetization loss) 및 통전손실(transport current loss)을 예측하고자 하는 연구가 진행되어 왔다 [7] - [10].

그러나, 대부분의 자화손실에 대한 연구는 외부자장에 대 한 경계조건이 잘 정의된 상태에서 시편에 대한 자화손실 측 정이나, 단순한 구조에서의 유한요소법에 의한 해석적 연구 에 국한되어 왔다.

특히, 벡터 포텐셜(vector potential)을 사용하는 일반 상용 해석 프로그램에서는 초전도체의 비선형 저항특성을 적용하게 되면 해석 시간이 매우 오래 걸리거나, 도체의 수 가 증가함에 따라 해석이 거의 불가능하게 된다.

따라서, 이러한 방법을 통해서는 초전도 코일 형상 자체 에 대하여 초전도 선재에 통전전류가 흐를 때 발생하는 통 전손실 예측이 매우 불편하거나 어렵게 된다.

본 연구에서는 능동형 자기재생식 (AMR; Active Magnetic Regenerative) 냉동기에 적용하기 위한 초전도 자석의 설계에 있어서, 기존의 초전도 선재 내에서 자체 통 전 전류 및 외부자장에 의한 통전 손실을 매우 효과적으로 해석할 수 있는 것으로 알려진 자기장 방정식 기반의 'edge element' 를 이용한 유한요소법(FEM; Finite Element Method)을 적용하고자 한다[9]. 특히, 기존의 2차원 평면 모델에서만 적용하던 자기장 방정식 기반의 "edge 
element' 모델을 2차원 축대칭 모델에 적용하기 위하여 자 기장 지배 방정식의 좌표변환을 통하여 코일 형상에 대한 통 전손실을 해석 방법을 제시하고자 한다.

또한, 손실의 예측에 있어서 기존의 이론식은 자장이 없을 경우의 임계전류를 적용하면 매우 큰 자화손실이 계산되는 반면, 최대 자장에서 임계전류에 대해 자화 손실을 계산하면, 매우 작은 자화 손실이 계산된다. 이러한 문제점은 실제 고자장 초전도 자석의 설계하는데 있어 발생할 수 있는 문제인데, 본 연구에서는 초전도 선재의 국부적인 임계전류를 자장의 함수로 적용함으로써 보다 정확한 손실 해석을 수행하고자 한다.

\section{2. 본 론}

2.1. 자기장 지배 방정식과 'edge element'

일반적인 전자장 해석은 맥스웰 방정식 (Maxwell Equation)을 기본으로 벡터 포텐셜을 이용하여 해석을 수행하게 된다. 그러나, 초전체의 경우 전류 밀도에 의해 결정되는 비저항이 비선형적이고 초전도 선재의 두께가 매우 얇기 때문에, 2 계 미분항을 포함하는 벡터 포턴셜에 의한 해석 방법은 해의 수렴에 매우 많은 시간을 필요로 한다. 본 논문에서는 Brambilla 등에 의해 제시된 'edge element' 를 이용한 자기장 지배방정식의 수치해석 방법을 적용하고자 한다[9].

전기장 $(\vec{E})$ 과 자기장 $(\vec{H})$ 전류 밀도 $(\vec{J})$ 에 대하여 상대 투자율이 1 일 경우 맥스웰 방정식 (1), (2), (3)으로부터 2차원 평면에서의 지배방정식을 유도할 수 있다.

$$
\begin{aligned}
& \mu \frac{\partial \vec{H}}{\partial t}+\nabla \times \vec{E}=0 \\
& \vec{J}=\nabla \times \vec{H} \\
& \nabla \cdot \vec{H}=0
\end{aligned}
$$

그리고, 전류밀도에 따른 초전도 선재의 비저항 $(\rho)$ 을 고려하면 전기장과 전류밀도는 식 (4)와 같이 표현된다,

$$
\vec{E}=\rho(J) \vec{J}
$$

여기서, 균일한 단면적을 갖고, $z$ 축 방향으로 무한히 긴 도체에 대하여, 직교 좌표계의 $\mathrm{x}-\mathrm{y}$ 평면상에서 자기장이 발생하하며, 자기장, 전기장 그리고 전류밀도 벡터는 식 (5) 와 같은 성분을 갖게 된다.

$$
\begin{aligned}
\vec{H} & =\left[H_{x}, H_{y}, 0\right] \\
\vec{E} & =\left[0,0, E_{z}\right] \\
\vec{J} & =\left[0,0, J_{z}\right]
\end{aligned}
$$

식 (5)를 식 (1)과 (2)에 대입하면 2차원 평면에서 식 (6), (7)의 식을 얻을 수 있게 된다.

$$
\mu \frac{\partial H_{x}}{\partial t}+\frac{\partial E_{z}}{\partial y}=0, \mu \frac{\partial H_{y}}{\partial t}-\frac{\partial E_{z}}{\partial y}=0
$$

$$
J_{z}=\frac{\partial H_{y}}{\partial x}-\frac{\partial H_{x}}{\partial y}
$$

따라서, 식 (6), (7)의 자기장 $\left(H_{x}, H_{y}\right)$ 을 독립변수로 하여 해석을 수행할 수 있게 된다. 벡터 포텐셜 도입하여 해석을 수행할 경우 자속밀도의 연속방정식 (3)이 자동적으로 만족하게 되지만, 본 논문의 해석에는 식 (3)에 대한 추가적인 구속조건을 필요로 한다. 식 (3)과 관련하여 유한요소법의 요소로서 'edge element' 를 선택함으로써 추가적인 구속 조건이 부가적인 방정식 없이 만족하게 된다. 또한, 'edge element' 는 초전도체와 같이 급격한 저항 변화를 갖는 비선형 문제 해의 수렴에도 적합한 것으로 알려져 있다 [9].

추가로 초전도체의 전류밀도에 대한 비저항 특성을 적용하면 식 (4)는 식 (8) 과 같이 표현된다.

$$
E_{z}=\frac{E_{0}}{J_{c}}\left|\frac{J_{z}}{J_{c}}\right|^{n-1} J_{z}
$$

여기서, $E_{0}, J_{c}, n$ 은 각각 임계전계 $(1 \mu \mathrm{V} / \mathrm{cm})$, 임계전류밀도 및 초전도 선재의 인덱스 값이다.

초전도 선재에 전류를 인가할 경우 식 (9)와 같이 시간에 따라 변화하는 도체의 통전 전류 $\left(I_{t r}\right)$ 에 대해서 초전도체 단면적 $(A)$ 에 대하여 내부 전류밀도 값을 적분한 후 추가적인 구속조건을 적용하게 해석을 수행할 수 있으며, 이때 발생하는 통전손실 $(P)$ 은 식 $(10)$ 과 같이 전기장과 전류밀도 곱의 적분 값으로 계산할 수 있다.

$$
\begin{aligned}
& I_{t r}(t)=\int_{A} J_{z} d A \\
& P=\int_{A} E_{z}{ }^{4} J_{z} d A
\end{aligned}
$$

여기서, 만일 해석하고자 하는 도체의 수가 증가할 경우 각각의 도체에 대하여 식 (9)와 (10)을 적용하면 된다.

앞서 기술한 해석 방법은 단일 도체의 통전손실 및 외부 자장 변화에 대한 자화손실뿐만 아니라, 초전도 케이블 형태에서도 그 해석 값이 매우 잘 일치하는 것으로 알려져 있다[9],[10].

그러나, 코일 형상의 해석에 있어서는 앞서 언급한 직교좌표계에서의 2차원 평면 해석이 아닌, 원통 좌표계에서 2 차원 축대칭 해석 모델을 필요로 한다.

따라서, 식 (5)는 $r, \Phi, z$ 좌표의 원통 좌표계에서 초전도 자석과 같은 축대칭 모델에 대하여 식 (11)과 같이 표현된다.

$$
\begin{aligned}
\vec{H} & =\left[H_{r}, 0, H_{z}\right] \\
\vec{E} & =\left[0, E_{\phi}, 0\right] \\
\vec{J} & =\left[0, J_{\phi}, 0\right]
\end{aligned}
$$

식 (11)을 다시 식 (1), (2)에 대입하여 원통 좌표계에서 전기장과 자기장에 대한 회전(curl)을 취하면 원통 좌표계에 대한 자기장 방정식 식 (12), (13)을 얻을 수 있게 된다.

$$
\mu \frac{\partial H_{r}}{\partial t}-\frac{\partial E_{\phi}}{\partial z}=0, \mu \frac{\partial H_{z}}{\partial t}+\frac{1}{r} \frac{\partial}{\partial y}\left(r E_{\phi}\right)=0
$$




$$
J_{\phi}=\frac{\partial H_{r}}{\partial z}-\frac{\partial H_{z}}{\partial r}
$$

위와 같이 원통 좌표계에서 축대칭 모델에 대하여 변형된 방정식 (12), (13)을 사용하게 되면, 평면 좌표계에서와 마찬가지로 원형 코일에 대한 통전 손실 및 자화 손실 해석을 수행할 수 있게 된다. 또한, 다층의 코일 권선에 대해서도 각 도체를 모델링하고, 각 도체에 흐르는 전류를 정의하게 되면 자장 분포에 대한 부가적인 가정 없이 직접 모든 도체에서 발생하는 손실 값을 계산 할 수 있게 된다.

\section{2. 고온 초전도 자석 사양}

능동형 자기재생식 냉동기에 적용하기 위한 고온 초전도 자석의 기본 사양은 최대 자장 $3 \mathrm{~T}$, 자장 변화율 $0.1 \mathrm{~T} / \mathrm{s}$ 의 성능을 나타내야 한다. 표 1은 설계에 적용된 고온 초전도 선재 사양으로서 $\mathrm{IBAD}$ 기판의 2 세대 초전도 선재를 적용하였다.

표 2는 본 논문에서 검토된 초전도 자석의 사양으로서 향후 상세 설계 및 최적 설계 결과에 따라 변경될 수 있으나, 본 논문의 요지는 축대칭 모델에서 통전손실의 해석이므로 표 2 의 자석 사양을 기준으로 해석 내용을 다루고자 한다.

\section{3. 해석 방법}

본 논문의 해석 모델을 적용하기 위하여 상용해석 프로그램인 'Comsol Multiphysics' 의 PDE (Partial Differential Equation) 모델을 사용하였으며, PDE 모델에서는 2 차원 축대칭 해석 모델을 기본적으로 지원하지 않기 때문에 2 차원 평면 모델의 지배방정식 일부를 수정하여 해석을 수행하였다.

본 논문에서 언급한 통전손실 해석 방법은 이론적으로 코일 단면의 모든 도체에 대하여 해석을 수행할 수 있으나, 해석 시간을 단축하고 인접한 초전도 선재에 의한 자기장 차폐효과를 알아보기 위하여 최상층 팬케이크 코일의 일부

TABLE 1

SPECIFICATIONS OF HTS WIRE

\begin{tabular}{lc}
\hline \multicolumn{1}{c}{ Parameter } & Value \\
\hline HTS conductor type & $\begin{array}{c}\text { ReBCO, IBAD substrate, } \\
\text { Copper plating } \\
\text { Width of conductor } \\
\text { Thickness of conductor }\end{array}$ \\
Thickness of HTS layer & $0.2 \mathrm{~mm}$ (including insulation layer) \\
Critical current (Ic) & $1 \mu \mathrm{m}$ \\
@77 K, self field & $141 \mathrm{~A}$ \\
\hline
\end{tabular}

TABLE 2

SPECIFICATIONS OF HTS MAGNET

\begin{tabular}{lc}
\hline \multicolumn{1}{c}{ Parameter } & Value \\
\hline Inner radius $\left(\mathrm{r}_{\mathrm{i}}\right)$ & $20 \mathrm{~mm}$ \\
Outer radius $\left(\mathrm{r}_{\mathrm{o}}\right)$ & $41 \mathrm{~mm}$ \\
Height of coil $(\mathrm{h})$ (including conduction plate & $72 \mathrm{~mm}$ \\
$\quad$ of 1 mm thickness) & 6 \\
No. of DPC (Double Pancake Coil) & $40 \mathrm{~K}$ \\
Operating temperature & $100 \mathrm{~A}$ \\
Max. operating current & $3 \mathrm{~T}$ \\
Max. magnetic field & $1 \mathrm{~T}$ \\
Max. perpendicular magnetic field & $0.1 \mathrm{~T} / \mathrm{s}$ \\
Max. magnetic field rate & $471 \mathrm{~m}$ \\
Total length of conductor & $40 \mathrm{~K}$ \\
Operating temperature & \\
\hline
\end{tabular}

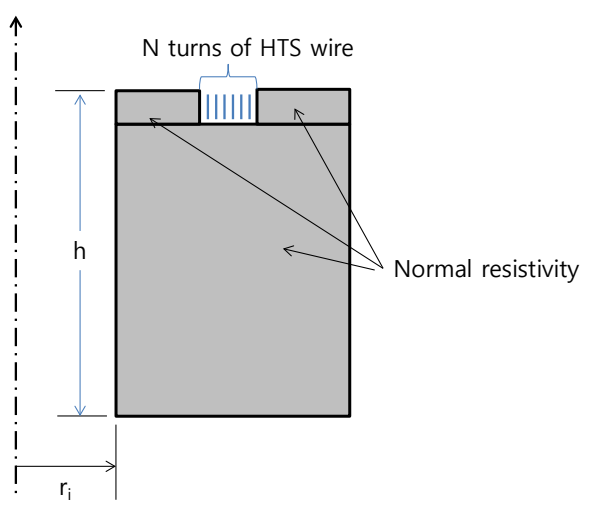

Fig. 1. Schematic diagram of analysis model.

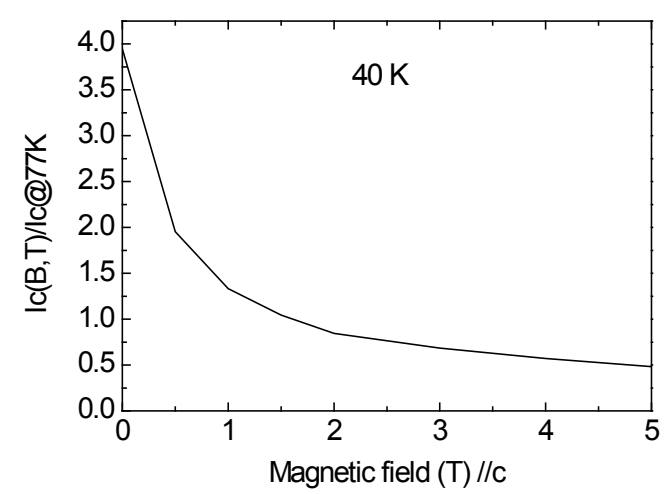

Fig. 2. Critical current of HTS wire under perpendicular magnetic field at $40 \mathrm{~K}$.

선재에 대하여 초전도체 저항 특성을 적용하였다. 그 외의 도체 영역은 초전도 선재 보다 매우 큰 전기 저항을 적용하여 균일한 전류 밀도 분포를 갖도록 하였다.

그림 1 은 해석 모델의 개략도이며, 전체 6 개의 $\mathrm{DPC}$ (Double Pancake Coil) 중에 최상층에 있는 하나의 팬케이크 코일 중심부 몇 개의 선재 턴에 대해서만 초전도체의 비저항 특성을 적용하여 통전손실 해석을 수행하였다. 본 논문에서는 초전도 선재 턴 수를 $1,3,5,7$, 9 개로 변경하면서 발생하는 통전손실 해석을 수행하였다. 초전도 선재 턴 수를 변화시킨 것은 선재 자체의 자기장 차폐효과가 인접한 도체의 통전손실에 미치는 영향을 알아보기 위한 것이다.

실체 초전도층의 두께인 $1 \mu \mathrm{m}$ 를 해석 모델에 직접 적용할 경우 메쉬 (mesh) 의 숫자가 너무 많아지기 때문에 해석의 편의성을 위해서 초전도층의 두께를 $10 \mu \mathrm{m}$ 로 모델링 하였다. $10 \mu \mathrm{m}$ 두께는 도체폭 $4 \mathrm{~mm}$ 에 비하여 여전히 매우 작은 값으로서 해석에서 두께 변화에 따른 임계전류밀도만 고려해 줄 경우 해석 결과에는 거의 영향을 미치지 않게 된다.

경계조건으로는 코일 외곽 해석 영역 경계에서 경계면에 수직한 방향 성분의 자기장 크기가 ' $O$ ' 인 것으로 하여 해석을 수행하였으며, 축에 대해서는 해석 모델이 축대칭 모델을 사용하므로 별도의 추가적인 경계조건을 부가하지 않았다.

또한, 초전도 도체는 자장이 증가함에 따라 임계전류가 감소하게 되는데, 이러한 자장 의존성은 실제 통전손실 해석에도 큰 영향을 미치게 된다. 따라서, 본 논문에서 자장 의존성을 갖는 초전도 선재의 임계전류 측정 값을 고려하여 


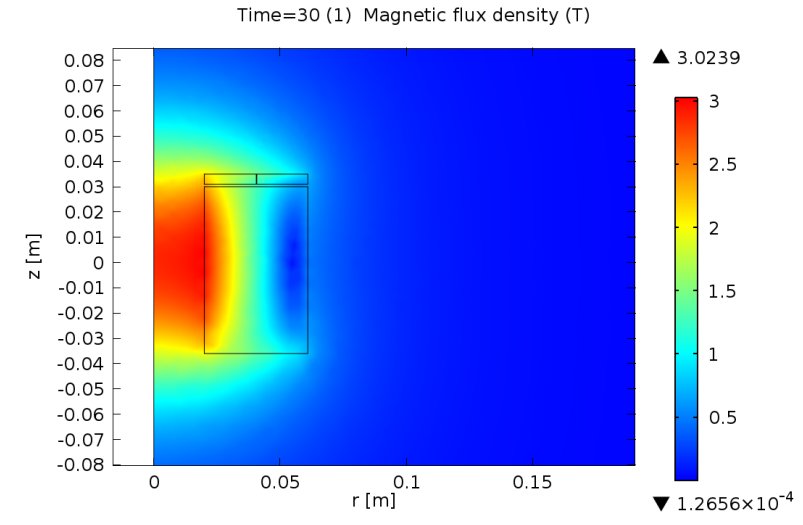

Fig. 3. Magnetic flux density and streamlines at $100 \mathrm{~A}, 30$ sec.

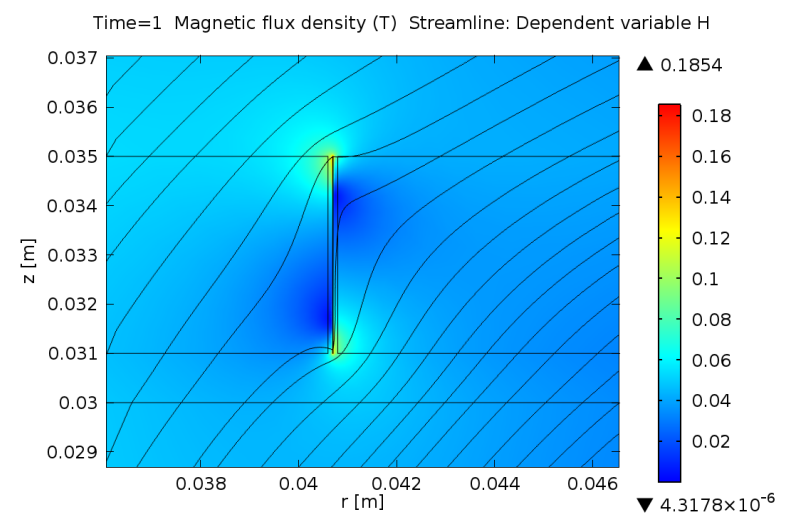

Fig. 4. Magnetic flux density and streamlines at $1 \mathrm{sec}$. around HTS wire.

해석을 수행하였다. 일반적인 이론식은 도체의 자장 의존성 자체를 고려할 수 없지만[11], 본 해석에서는 단순히 도체의 임계전류밀도를 도체에 작용하는 수직자장의 함수로 적용함으로써 자장에 의한 영향을 해석할 수 있게 된다.

그림 2 는 본 논문에서 고려된 초전도 선재의 수직 자장에 대한 임계전류 측정 결과이다.

\section{4. 단일 선재 해석 결과}

그림 3 은 1 개의 초전도 선재만을 고려하고, 통전 전류가 100 A일 때의 자기장 분포를 보여준다. 해석 결과는 초전도체 부분을 제외하고는 일반적인 상용 자장 해석 프로그램의 결과와 일치함을 알 수 있었다. 그림 4 는 1 개의 초전도 선재에 대하여 1 초 후 즉, 통전전류가 $3.3 \mathrm{~A}$ 일 때 초전도 선재 주변의 자기장을 나타내며, 차폐 전류에 의한 자기장 차폐효과가 발생하고 있음을 알 수 있다.

그림 5 는 초전도 선재가 1 개일 때 초전도체 내부의 전류 분포 변화를 나타내며 초전도체의 전형적인 이론적 전류 분포와 유사한 결과를 보여준다[11]. 초기에는 외부 자기장의 영향을 받아 차폐전류가 초전도체 양 끝 단에서 형성되는 것을 보여주며, 시간이 지날수록 차폐전류뿐만 아니라, 통전 전류의 증가에 따른 전체 전류 분포의 변화를 보여주고 있다.

약 5초 이후에 이미 외부자기장에 의한 차폐전류는 포화된 형태를 보여준다. 이후 계속된 통전 전류 및 주변

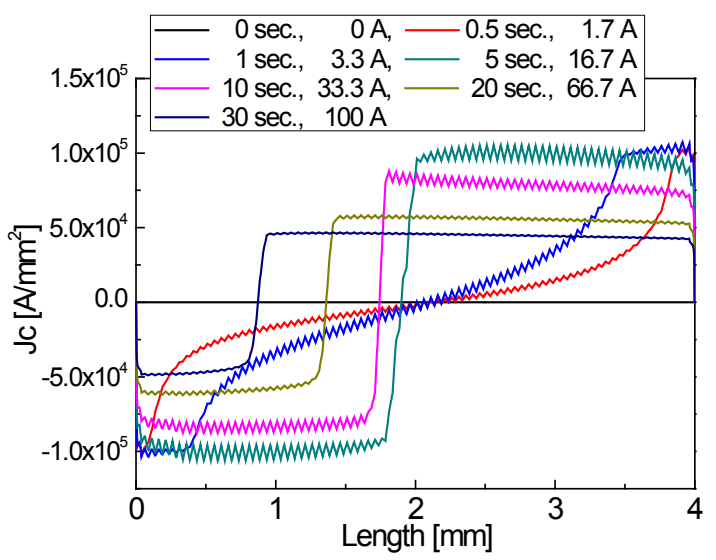

Fig. 5. Current distributions along the HTS layer at different transport currents for single conductor.

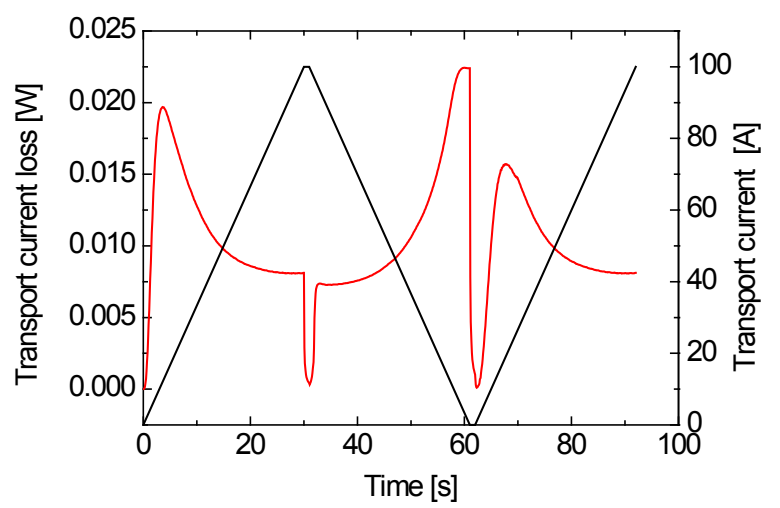

Fig. 6. Transport current loss of HTS wire for varying magnetic field and transport current for single conductor.

자기장의 증가에 따라 임계전류의 감소와 함께 초전도체 양 끝단의 포화되는 전류의 크기가 함께 감소함을 알 수 있다.

그림 6 은 그림 5 의 전류 분포를 갖는 초전도 선재에 대하여 통전 전류의 변화에 따른 초전도체 통전손실의 순시 값으로서 식 (10)을 이용하여 계산된 값이다. 그림 5의 전류 분포에서 예측할 수 있듯이 초기 전류 및 자장 증가에 따라 통전손실이 증가하지만, 계속된 자기장 증가에 따른 임계전류의 감소 효과에 의하여 통전손실이 다시 감소하는 결과를 보여준다.

0 30 초까지는 초전도체의 초기 전류 밀도 분포가 모두 0 인 상태에서 시작된 결과이며, 실제 초전도 자석의 연속 운전시에는 31 61초까지 전류/자기장이 감소할 때와 62 63초까지 전류/자기장이 증가할 때의 손실이 발생한다

해석 결과에서 볼 수 있듯이, 자기장 세기에 의존하는 임계전류밀도를 고려함으로써, 자장이 증가함에 따라 통전손실이 감소하는 결과를 얻을 수 있었다. 그리고 그림 6 의 해석 결과는 단지 외부 자기장에 의한 통전손실만이 고려된 것이 아니라, 통전 전류 자체에 의한 영향도 함께 고려된 해석 결과이다.

\section{5. 적층 선재 해석 결과}

초전도 선재의 적층 효과를 검토하기 위하여 앞서의 1 개 선재를 중심으로 총 $3,5,7,9$ 개의 초전도 선재가 있을 때의 통전손실 해석을 동일한 방법으로 수행하였다. 단일 선재 


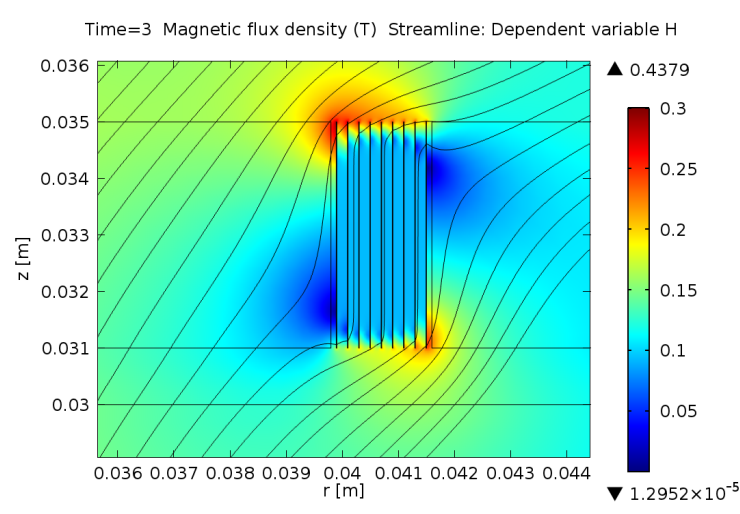

(a)

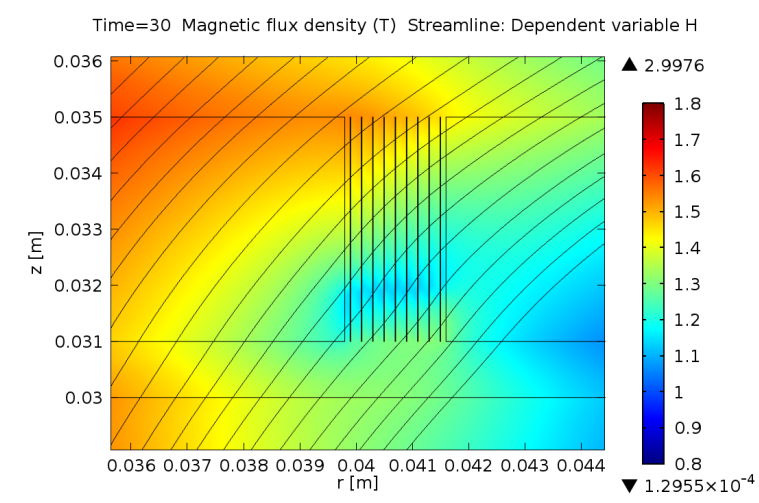

(b)

Fig. 7. Magnetic flux density and streamlines around the stacked conductors at (a) $3 \mathrm{sec}$., and (b) $30 \mathrm{sec}$.

해석과 마찬가지로 각 선재에 흐르는 전류는 초전도 선재 단면에서 전류밀도 적분값에 대하여 추가적인 구속조건을 부여함으로써, 동일한 통전전류가 흐르도록 하였다.

그림 7 은 초전도 선재의 수가 11 개일 때 3 초 및 30 초에서 적층된 초전도 선재 주변의 자기장 분포를 나타낸다. 그림 7 (a)에서 볼 수 있듯이 해석에서 고려된 초전도 선재 숫자가 증가하였을 경우, 중심부에 위치한 선재는 이웃한 선재의 자장 차폐효과에 의해 외부자장에 의한 영향을 적게 받는 것을 알 수 있다. 그러나, 그림 7 (b) 와 같이 시간이 지남에 따라 이미 차폐전류가 포화되고 선재 내 전류분포가 총 통전 전류의 크기에 영향을 받게 됨에 따라 이웃한 도체에 의한 차폐효과가 감소함을 알 수 있다.

그림 8은 해석에서 고려된 초전도 선재의 수가 증가함에 따라 중심부에 위치한 초전도 선재에서 발생하는 통전손실 값의 변화를 보여주며, 평균 손실량은 30초에서 92 초까지의 손실량의 평균 값으로서 실제 연속 충방전을 하는 초전도 자석에서 발생하는 통전손실의 평균값이 된다.

자장 차폐 효과로 인하여 중심부 초전도 선재에서 발생하는 통전손실의 크기는 적층 선재의 수가 증가할수록 감소하는 결과를 얻을 수 있었으며, 처음 3 개 적층 선재 모델에서 손실 감소량이 가장 컸으며, 적층 수가 계속 증가함에 따라 손실 감소폭은 점차 감소하는 것을 알 수 있었다.

그림 9 는 0 초에서 154 초까지 연속적으로 전류를 충전 및 방전을 하였을 때 각각 반주기 동안에 발생하는 평균 통전 손실을 보여준다. 본 해석 모델에서는 $100 \mathrm{~A}$ 이하에서 이미 차폐전류가 포화되기 때문에 처음 충전시 (0 30초) 를 제외하고는 반복적인 평균 손실 값을 얻을 수

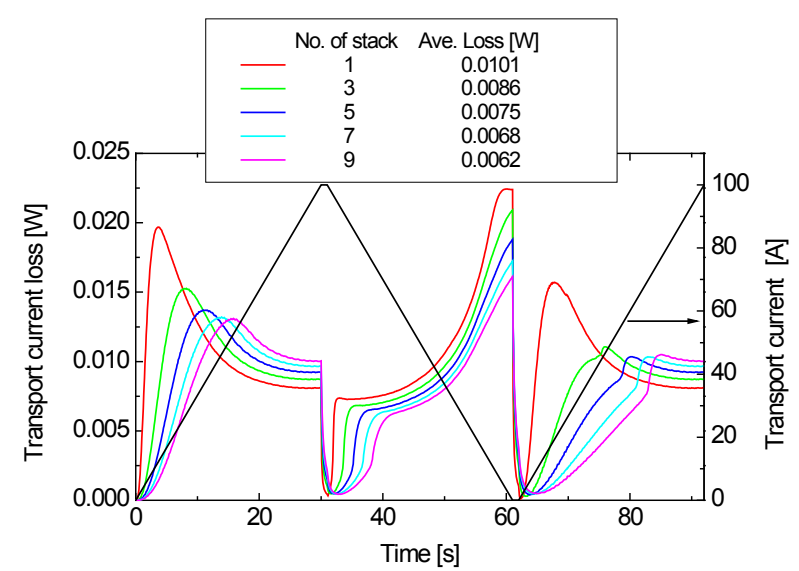

Fig. 8. Time varying transport current losses for various stacked numbers of HTS wire and the averaged loss from $30 \mathrm{sec}$. to $92 \mathrm{sec}$.

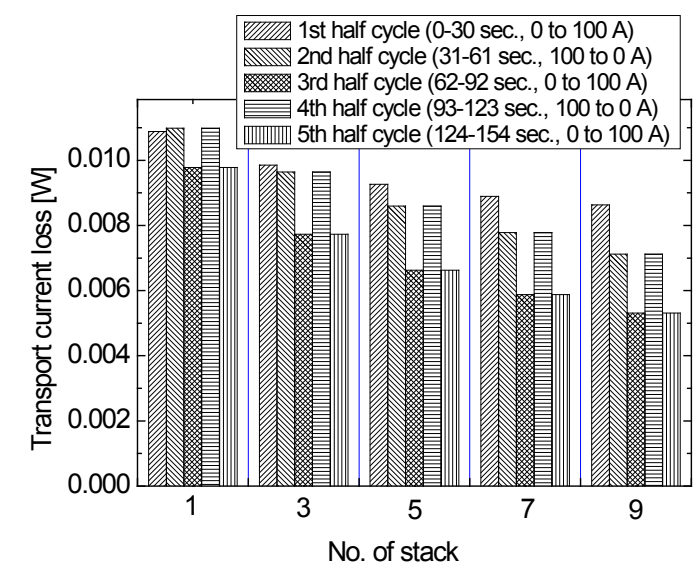

Fig. 9. Comparison of averaged transport current loss for each step of charging and discharging periods.

있었다. 즉, 처음 충전시를 제외하고는 그 다음 반주기부터는 방전할 때와 충전할 때의 평균 손실량이 다를 뿐 반복적인 평균 손실 값을 보임을 알 수 있었다.

전체적으로 충전시보다는 방전시에 더 많은 손실이 발생하는 것을 알 수 있는데 이는 그림 8의 결과에서 보듯이 충전시에는 자장이 증가하며 도체의 임계전류가 감소하고 방전시에는 자장이 감소하며 도체의 임계전류 증가 때문이다.

\section{3. 결 론}

자기장 지배 방정식과 ‘edge element' 를 이용하여 초전도 자석에서 발생하는 통전손실에 대한 해석을 수행하였다. 특히, 지배방정식을 원통 좌표계에서 축대칭 모델에 적용함으로써, 코일 형상에서의 통진손실 해석을 수행할 수 있었으며, 외부 자기장의 영향을 별도의 경 계조건이나, 입력 변수로 사용하지 않고 코일 형상 전체에 대하여 해석을 수행할 수 있었다.

코일 형상에서 적층된 선재의 상호 작용 및 임계전류변화에 의한 통전손실 특성 해석을 수행할 수 있었으며, 이웃한 선재에 의한 차폐전류 효과를 정량적으로 해석 할 수 있었다. 
능동형 자기 재생식 냉동기의 적용에 있어 보다 상세한 해석 결과를 필요로 하지만, 9개 선재 적층 모델에서, 통전손실이 가장 크게 발생할 것으로 예측되는 최상단 팬케이크 코일의 중앙부 선재에서 발생하는 통전손실이 $0.0062 \mathrm{~W} / \mathrm{m}$ 이므로, 이를 $471 \mathrm{~m}$ 의 전체 선재 길이를 고려하더라도 최대 $3 \mathrm{~W}$ 이내의 손실이 발생할 것으로 예측된다. 향후 각 선재의 위치 따른 대한 손실 값 계산을 통하여 전체 단면적에 대한 손실을 계산할 계획이다.

본 논문에서 제시한 해석 방법은 기존의 벡터 포텐셜 해석 방법에 비하여 매우 빠른 해석이 가능하므로, 향후 더욱 많은 숫자의 초전도 선재를 고려한 해석을 진행할 수 있을 것으로 판단된다. 본 논문에서는 $3.2 \mathrm{GHz} 6$ core, 16 $\mathrm{GB}$ 데스크탑 컴퓨터에서 1.5 주기에 해당하는 92 초의 비정상해석을 위하여 단일 초전도 선재일 경우 21 분, 9 개 선재를 고려하더라도 65 분이 소요되었다. 물론, 실제 모든 초전도 선재를 다 고려하여 해석을 수행하기에는 너무 많은 해석 시간을 필요로 하겠지만, 관심 영역의 도체에 대하여 수십 턴 정도까지는 초전도체로 해석하는데 큰 무리가 없을 것으로 판단된다.

이러한 해석 기법을 바탕으로 한류기나 변압기와 같이 축대칭 형상을 갖는 초전도 자석에서 형상 설계 및 도체 분할에 따른 손실 저감 효과를 해석상의 별다른 가정 없이 수치적인 방법을 통하여 정량적으로 예측하는데도 활용될 수 있을 것이다. 또한, NMR 인서트 및 MRI에 사용하기 위한 고온초전도 자석에서 차폐전류에 의한 자기장 왜곡 및 잔류 자기장 해석에도 적용될 수 있을 것으로 판단된다.

향후 본 논문에서 사용된 해석 기법의 검증 및 보완을 위하여 실제 제작된 고온 초전도 코일의 실험 결과와 비교할 예정이다.

\section{ACKNOWLEDGMENT}

이 논문은 2012년도 정부(교육과학기술부)의 재원으 로 휴먼인지환경사업본부-신기술융합형 성장동력사업의 지원을 받아 수행된 연구임 (2012K-001434).

\section{REFERENCES}

[1] W. Iwasaki, "Magnetic refrigeration technology for an international clean energy network using hydrogen energy (WE-NET)", Int. J. Hydrogen Energy, vol. 28, pp. 559-567, 2003.

[2] K. Kamiya, H. Takahashi, T. Numazawa,H. Nozawa, T. Yanagitani, "Hydrogen Liquefaction by Magnetic Refrigeration",Cryocooler, vol. 14, pp. 637-644, 2007

[3] J. Park, Y. Kim, S. Jeong, S. Kim, "Design of adiabatic demagnetization refrigerator for hydroge re-liquefaction", Superconductivity and cryogenics, vol. 14, no. 3., pp. 53-59, 2012

[4] A. Kitannovski, P. W. Egolf, "Thermodynamics of magnetic refrigeration", Int. J. Refrigeration, vol. 29, pp. 3-21, 2006.

[5] 이지광, 임형우 박명진, 차귀수, "BSCCO tape 선재와 $\mathrm{YBCO}$ $\mathrm{CC}$ 의 외부자장 각도에 따른 자화손실 특성비교," 전기학회 논문지, 전기기기 및 에너지변환부문, vol. 54 , no. 12 , pp. 586-591, 2005

[6] 이지광, 임형우, 차귀수, "대전류 통전을 위한 $\mathrm{YVCO} \mathrm{CC}$ 적층선재의 자화손실 특성," 한국초전도 저온공학회 논문지, vol. 9, no. 1, pp. 27-31, 2007

[7] 박명진, 임형우, 이광연, “적층 배열형상에 따른 $\mathrm{BSCCO}$ 적층 선재의 자화손실 특성 수치해석 및 측정," 전기학회논문지 전기기기 및 에너지변환시스템부문, vol. 55 , no. 2, pp. 83-88, 2006

[8] N. Amemiya and M. Nakahata, "Numerical study on AC loss characteristics of superconducting power transmission cables comprising coated conductors with magnetic substrates," Physica C, vol. 463-465, pp. 775-780, 2007.

[9] R. Brambilla, F. Grilli and L. Martini, "Development of an edge-element model for AC loss computation of high-temperature superconductors," Supercond. Sci. Technol., vol. 20, pp. 16-24, 2007.

[10] S. Kim, K. Sim. J. Cho, H. Jang and M. Park, “ AC loss analysis of HTS power cable with RABitS coated conductors," IEEE Trans. Appl. Supercon., vol. 20, no. 3, pp. 2130-2133, 2010 .

[11] E. H. Brant, M. Indenbom, "Type-II-superconductor strip with current in a perpendicular magnetic field", Phys. Rev. B, vol. 48, pp. 12893-12906, 1993. 